\title{
Verzeichnis
}

\section{der Herren, welche für den einundzwanzigsten Band Referate geliefert haben.}

(Die Verantwortlichkeit für den Inhalt der Referate tragen die Herren Referenten. Die in Klammern gesetzten Chiffern bezeichnen die Uebersetzer der in fremder Sprache eingesandten Referate.)

A. Herr Prof. August in Berlin.

Bb. ᄁ Professor Bobylew in

St. Petersburg.

Bk. „ Dr. Buka in Charlottenburg.

Bm. " Prof. v. Braunmühl in München.

Bö. \# Dr. Börsch in Potsdam.

Cly. " Prof. Cayley in Cambridge.

Dn. " Dickstein in Warschau.

Dz. " Dr. Dziobek in Char-

E. Prof. G. Eneström in lottenburg.

E. K. „ Dr. E. Kötter in Berlin.

El. " Prof. Engel in Leipzig.

F. "Dr. Faerber in Berlin.

F. K. " Dr. F. Kötter in Berlin.

Fm. " J. Fredholm in Stockholm.

G. " Prof. van Geer in Leiden.

Gbs. " Assist. Prof. Gibs on in

Glr. „ Prof. Glaisher in Cam-

" bridge.

Gr. ऋ Prof. Günther in München.

Gz. \# A. Gutzmer in Berlin.

H. $~$ Prof. Hoppe in Berlin.

Hk. " Prof. Hauck in Berlin.

Hr. " Prof. Hamburger in Berlin.

Ht. ” Prof.Hilbert in Königsberg

Hz. \ Prof. Hurwitz in Zürich.

Kr. " Prof. Krazer in Strassburg.

La. " Prof. Loria in Genua.

Lbg. " Prof. Lorberg in Bonn.

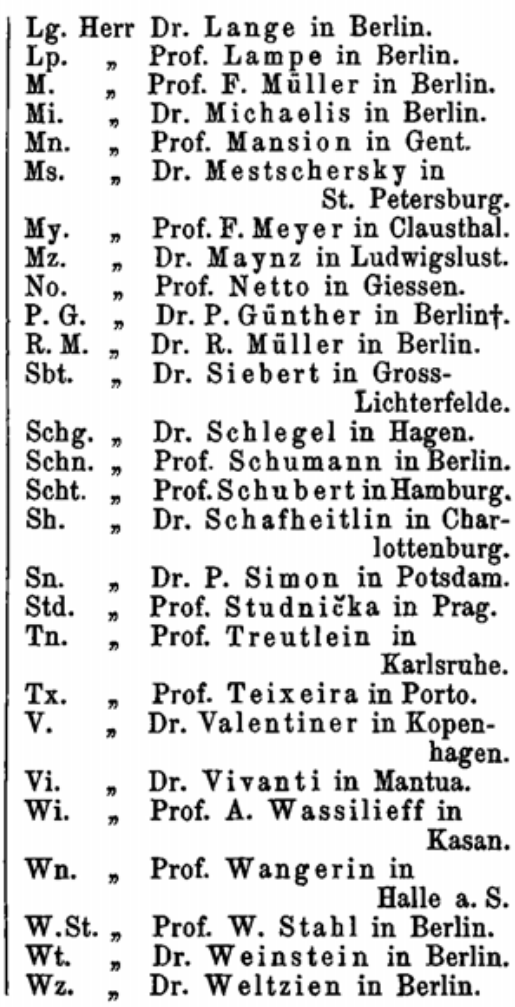

Briefe und Zusendungen erbitten wir entweder durch Vermittelung der Verlagshandlung oder unter der Adresse:

Professor Dr. Lampe, Berlin W, Kurfürstenstr. 139. 